\title{
Proceeding
}

Supplementary Issue: Spring Conferences of Sports Science. III International Congress on Research and Didactics of Physical Education, 15-16 March 2018. Granada, Spain

\section{Mood states and levels of physical activity in adults: Regression analysis}

\author{
FÁTIMA CHACÓN-BORREGO , CAROLINA CASTAÑEDA-VÁZQUEZ, JUAN ANTONIO CORRAL- \\ PERNÍA
}

Department of Physical Education and Sport, University of Seville, Spain

\begin{abstract}
Mood States (MS), as elements which are part of psychological wellbeing, must be subject to improvement through physical activity (PA) and its possible consequences on health. For this purpose, the present research aims to analyze and describe the possible relations of the different levels of PA with the positive and negative feelings with regard to MSs and gender. Participants were 1,002 individuals ( $\geq 18$ years old, $52.9 \%$ women) who were applied: International Physical Activity Questionnaire (IPAQ) and Mood States Questionnaire (MSQ). Bivariate correlations (Spearman) and the analysis of binary logistic regression were also carried out. Data show significant correlations of low magnitude between the MSs of "sadness, tiredness and liveliness" and the levels of PA. It can be concluded that PA based on the global recommendations of a healthy practice would have a beneficial effect on the MS of individuals, and therefore it would contribute to implement their psychological health. Key words: MOOD DISORDERS, EXERCISE, IPAQ, EMOTIONS, GENDER.
\end{abstract}

\section{Cite this article as:}

Chacón-Borrego, F., Castañeda-Vázquez, C., \& Corral-Pernía, J.A. (2018). Mood states and levels of physical activity in adults: Regression analysis. Journal of Human Sport and Exercise, 13(2proc), S199-S208. doi:https://doi.org/10.14198/ihse.2018.13.Proc2.04

Corresponding author. Department of Physical Education and Sport, University of Seville, Spain. https://orcid.org/0000-0002$1499-2552$

E-mail: fchacon@us.es

Supplementary Issue: Spring Conferences of Sports Science. III International Congress on Research and Didactics of Physical Education, 15-16 March 2018. Granada, Spain.

JOURNAL OF HUMAN SPORT \& EXERCISE ISSN 1988-5202

(c) Faculty of Education. University of Alicante

doi: 10.14198/jhse.2018.13.Proc2.04 


\section{INTRODUCTION}

Mood states (MS) are part of an individual's psychological wellbeing, and therefore they have possible effects on health. Several research have pointed out that a lower presence of negative mood states (NMS) (Badenes et al., 2016; Fang et al., 2008; Glaser and Kiecolt-Glaser, 2005) and a higher presence of positive mood states (PMS) (Barak, 2006; Cohen et al., 2006; Vázquez et al., 2009), can have an effect on the appearance of specific illnesses, psychological and physical alterations, and even on recovery processes.

Conversely, physical activity (PA) brings many benefits to health from a psychological point of view. On the one hand, it contributes to improve the state of psychological wellbeing (Arruza et al., 2008; Barra Almagiá, 2003; Jiménez et al., 2008; Taylor et al., 2000). On the other hand, it helps to reduce the risk of suffering mental illnesses, anxiety and depression states, as well as it increases self-concept, self-determination or levels of resilience (Fernández et al., 2015; Lawlor and Hopker, 2001; Varo et al., 2003; Zurita et al., 2016).

A relation between MS and PA has also been considered. Studies that analyze such factors are mostly framed within the scope of competitive sport. Nevertheless, other research within the field of the practice of leisure-time and health related PA have also been identified, where it has been noticed how physically active people present improved MS, with a lower presence of NMS (depression, stress or fatigue) and simultaneously a higher presence of the positive MS of "vigor" (Andrade et al., 2011; Berger and Motl, 2000; Chacón-Borrego et al., 2017; García et al.,, 2015; Oiarbide, Martínez de Santos et al., 2014; Portela-Pino et al., 2017; Rey et al., 2000; Ruiz and Baena, 2011).

However, different recommendations about PA in adults and older adults, such as those made by the U.S. Department of Health And Human Services (2008), the World Health Organization (WHO, 2010), or the Ministry of Health, Social Services and Equality (2017), state that the performance of certain levels of PA contributes to the improvement of cardiorespiratory, muscular, joint aspects, and it could also reduce levels of anxiety, depression and cognitive deterioration.

On this basis, just as it has been studied how the performance of PA has a positive effect on the MS, it is important to determine which levels of PA are the most suitable to produce such improvements and whether, as the aforementioned recommendations show, people who perform moderate and/or vigorous activities in the established time slots, are those who present better MS with respect to sedentary people or people with a low level of PA. Thus, the most logic hypothesis to be highlighted, and the one which lays the foundation for the present study, would be that a practice in accordance to the recommendations of healthy PA, set out by the different bodies mentioned above, would contribute to maintaining a good psychological health (not only physical), having a favorable effect on the MS of individuals who comply with such recommendations.

Scientific evidences about levels of PA and MS in adults, are not conclusive. In general, it can be stated that vigorous activity brings larger improvements of MS, with a decrease of NMS and an increase of PMS, although these improvements are not similar in all the dimensions of MSs and neither the differences of MS among the levels of PA are always significant. (Arruza et al., 2007; Beedie et al., 2008; Bonet et al., 2017; Cervelló et al., 2014; Deepthi et al., 2015; Leon-Prados et al., 2012; Noce et al., 2016; Reed and Ones, 2006). Based on what was previously stated, the present research intends to analyze and describe the possible relations of the different levels of PA with the positive and negative feelings of the MS and gender. 


\section{MATERIAL AND METHODS}

The present research is framed within the context of a non-experimental, descriptive and correlational crosssectional study.

\section{Participants}

The sample comprised 1,002 individuals aged $\geq 18$ years old, living in the city of Seville. Among the surveyed individuals, there were 531 women (52.9\%) and 471 men (47.1\%). The sampling method was stratified and random for the eleven city districts, and subsequently selected responding to age and gender quotas for each district. The level of trust was established in $95.5 \%$, being $\pm 3.01 \%$ the estimated error for the whole sample.

\section{Measures}

Short version of the International Physical Activity Questionnaire (IPAQ) was used in order to determine individuals physical activity levels (Craig et al., 2003). This instrument evaluates the level of PA through the frequency (days per week), duration (duration of time per day), and intensity (moderate, vigorous PA, walking) of the PA performed in a week.

In order to analyze data obtained through IPAQ questionnaire, a categorical PA index was created, giving rise to three PA groups according to IPAQ instructions (Fernández et al., 2005).

The Mood States Questionnaire (MSQ) developed by Arruza et al. (2007), was used for the MS assessment. It consists of a scale of 5 items where respondents are questioned about the presence of positive feelings (liveliness feeling) and negative feelings (restlessness, sadness, tiredness or bad mood) in the last year. Each item is valued in a Likert scale from 1 to 5 points, where $1=$ "nothing or none" and $5=$ "considerable". The global Cronbach's alpha intern validation coefficient of the questionnaire was .64.

\section{Procedures}

Data were collected by means of personalized interviews approaching homes and the following exclusion criteria were established: interviews in areas closed to sports facilities, public transport stops or stations, or school centers. On the other hand, inclusion criteria were established, people with homes in the assigned district for the survey; and fulfillment of the established age and gender quotas.

\section{Analysis}

Normality of the included variables was determined through the Kolgomorov-Smirnov test with Lilliefors correction. The descriptive statistics is presented with means and typical variances, as well as with percentages for the analyzed variables. The chi square test was used (with analysis of residuals) for the categorical variables. Bivariate correlations were also applied delivering the Spearman correlation coefficient to test the level and the relationship direction among the different variables of the survey. The correlation level was established following the recommendations of the experts (Pulver et al., 1988). In contrast, a binary logistics regression analysis was carried out to determine those analyzed explanatory variables of the different MS. Besides, the level of association among the different MS and the levels of PA and gender was calculated. In this case, the Odds Ratio (OR) was used and its $95 \%$ of level of trust, as the result. For all the tests, the level of significance was fixed in $p<.05$. All the analysis were developed with the SPSS statistics 24.0. version. (SPSS, Inc., Chicago, IL). 


\section{RESULTS}

After an analysis of the results of the MS, Table 1 shows that the perception of NMS (restlessness, sadness, tiredness and bad mood) is higher in women than in men (finding significant differences), whereas men present higher values in the MS of "liveliness". However, men present a higher level of PA than women, although differences are not significant.

Table 1.Level of PA and perception of MS in Seville adult population

\begin{tabular}{lccc}
\hline & Man & Woman & $\boldsymbol{P}^{\boldsymbol{a}}$ \\
\hline Level of PA & $2.14(.62)$ & $2.10(.57)$ & .212 \\
Uneasiness & $2.63(1.31)$ & $2.99(1.29)$ & $<.001$ \\
Sadness & $1.85(1.08)$ & $2.45(1.32)$ & $<.001$ \\
Tiredness & $2.55(1.18)$ & $3.19(1.24)$ & $<.001$ \\
Liveliness & $3.76(1.05)$ & $3.41(1.14)$ & $<.001$ \\
Bad mood & $1.99(1.07)$ & $2.17(1.13)$ & $\mathbf{0 1 2 9}$ \\
\hline
\end{tabular}

Note:*Values expressed as Mean (DE); $P^{a}$ : significance of $p$-value in Chi Square test.

In this sense, in the perception of the MS, when grouping the values of "little"-"sufficient"-"considerable" and "very much" in the presence category, against the value "none" in the category of absence of the different feelings, the following results are obtained (Table 2). The feelings with a higher occurrence are "liveliness, tiredness and restlessness" $(96.7 \%, 82.3 \%$ and $79.8 \%$, respectively). In a second level of occurrence the feelings of "sadness and bad mood" are found; around $40 \%$ of population state not having had this feeling "at all" in the last year.

Table 2. Perception of the MS of Seville adult population

\begin{tabular}{lcc}
\hline Feelings & Presence* & Absence** \\
\hline Restlessness & 79.8 & 20.2 \\
Sadness & 58.9 & 41.1 \\
Tiredness & 82.3 & 17.7 \\
Liveliness & 96.7 & 3.3 \\
Bad mood & 62.2 & 37.8 \\
\hline
\end{tabular}

Note: Values expressed as percentages (\%)* Presence (values: a little, moderately sufficient considerable and very much) **Absence (values: none)

Once the correlations between the level and quantity of PA and the MS in the last year has been assessed, it must be noticed that significant correlations of low magnitude have been identified between the MS of "sadness, tiredness and liveliness" and the levels of PA. NMS correlate favorably with the low level of PA and PMS correlate with this level adversely; nonetheless, the levels of a medium and high PA correlate negatively with NMS and favorably with PMS. 
Table 3. Spearman correlation between the level of PA measured with the IPAQ questionnaire and MSs in Seville adult population $(\mathrm{n}=1002)$

\begin{tabular}{lcc}
\hline Mood states & Low level of PA & Medium-high level of PA \\
\hline Restlessness & -.055 & .055 \\
Sadness & $.121^{* *}$ & $-.121^{* *}$ \\
Tiredness & $.086^{* *}$ & $-.086^{* *}$ \\
Liveliness & $-.206^{* *}$ & $.206^{* *}$ \\
Bad Mood & -.048 & .048 \\
\hline
\end{tabular}

Note: * the correlation is significant at .05 level, ** correlation is significant at .001 level

Finally, a set of binary logistics regressions is presented. They associate MS with the levels of PA and gender.

Therefore, Table 4 displays how $4.8 \%$ of the MS variance of "sadness" is explained due to the low level of PA and gender.

Similarly, it should be pointed out that a low level of PA presents significant associations $(p<.05)$ with the MS of "sadness", with an OR of 2.010, as well as significant associations $(p<.001)$ with gender $(O R=2.248)$.

Table 4. Binary explanatory logistics regression of the existing variance in Seville adult population with a MS of "sadness".

\begin{tabular}{lccccr}
\hline \multicolumn{1}{c}{ Model (-2 Log likelihood=1221.473; Cox \& Snell R Square=.048; Nagelkerke R Square= .064) } \\
\hline \multicolumn{1}{c}{ Variables } & Coefficient & Error est. & $\begin{array}{c}\text { Wald } \\
\text { Statistic }\end{array}$ & OR (95\% IC) & $p^{\dagger}$ \\
\hline Low level of PA & .698 & .223 & 9.811 & $2.010(1.299$ to 3.112) & .002 \\
Gender & .810 & .136 & 35.265 & $2.248(1.721$ to 2.937) & .000 \\
Constant & -.114 & .100 & 1.295 & .893 & .255 \\
\hline
\end{tabular}

Note: OR: Odds ratio; IC: Confidence interval; $p^{\dagger}: p$ value from Chi Square analysis

With respect to the MS of "liveliness", 1.1\% of its variation is explained due to the low level of PA, presenting significant associations ( $p<.001)$, with an OR of 0,240 .

Table 5. Explanatory binary logistics regression of the existing variance in Seville adult population presenting a MS of "liveliness".

\begin{tabular}{lccccc}
\hline \multicolumn{1}{l}{ Model (-2 Log likelihood=241.440; Cox \& Snell R Square=.011; Nagelkerke R Square= .047) } \\
\hline \multicolumn{1}{c}{ Variables } & Coefficient & Error est. & $\begin{array}{c}\text { Wald } \\
\text { Stadistic }\end{array}$ & OR (95\% IC) & $p^{\dagger}$ \\
\hline Low level of PA & -1.428 & .408 & 12.269 & $.240(.108$ to .533) & .000 \\
Constant & 3.798 & .238 & 253.952 & 44.611 & .000 \\
\hline
\end{tabular}

Note: OR: Odds ratio; IC: Confidence interval; $p^{\dagger}: p$ value from Chi Square analysis 


\section{DISCUSSION}

The present study describes and analyzes possible relations among the different levels of PA with positive and negative feelings of the MS and gender.

According to data collected, it has been observed a higher index of practice of PA in men with respect to women. Although the differences have not become significant, it is a fact already noted in numerous previous works (Castañeda et al., 2012; García and Llopis, 2001; Romero et al., 2010).

With regard to the difference of MS concerning the gender of the population, data collected agree upon previous research as those carried out by Arruza et al. (2008) or Shin and Colling (2000), which highlighted a higher presence of NMS in women with respect to men.

Among the most referred feelings in people interviewed, the most noted was that of "liveliness", although the feelings of "tiredness and restlessness" are mentioned right after that. Thus, it could be concluded that Seville adult population show in a general sense a PMS, being men those reporting positive feelings, like "liveliness" in a higher degree than women.

In terms of the relation between MS and PA, some previous research like Noce, et al. (2016), who also considered the influence of the level of PA over the MS of individuals, had not managed to establish significant differences between such levels and the MS of individuals, in spite of the fact that active individuals had had better scores in feelings like "vigor" than sedentary ones.

Nonetheless, data gathered for this study show significant correlations between the level of PA with the MS, specifically between the NMS of "sadness and tiredness", with a low level of PA, and the feeling of "liveliness", with a medium-high level of PA.

In Arruza et al. (2007) people with a high level of PA also noted having experienced "restlessness" in a lesser extent than individuals with a low level of PA. Even though the differences did not prove to be significant in the case of the feelings of "sadness, tiredness and liveliness", data collected were very interesting, since as people were gradually more active physically, results suggested a lower feeling of "tiredness" during the last year. Similarly, the group with a low level of PA has been feeling lively to a lesser extent than the group with moderate and high PA.

Results from Leon-Prados et al. (2012) were also in accordance with those presented, since it was stated that regardless of age and gender, the amount of PA performed relates in a negative manner with NMS and in a positive manner with PMS. However, one of the observations made was the need to quantify the amount of PA necessary for such improvements to reflect in the psychological wellbeing, a piece of information which is tried to be provided in the present research.

Other works like Cervelló et al. (2014) and Arruza et al. (2008) had already associated factors like intensity and length of the PA respectively with MS, in the sense that a longer length and higher intensity of the exercise provide a better psychological wellbeing. Bonet et al. (2017) noted that PA had a positive effect on the MS of individuals, despite their level of activity. However, such effect resulted more beneficial in active participants. Besides, significant differences were obtained in the "depression or sadness" feelings between active and non active participants, being active people the ones who showed a more significant decrease of that feeling after the exercise. 
Additionally, analysed regressions have associated the low level of PA with gender and the feeling of "sadness", as well as a low level of PA with the feeling of "liveliness", although a relationship with the rest of NMS feelings has not been registered. These data cannot be contrasted with other similar studies since scientific evidences in this same direction have not been found.

Results collected point at the direction of the hypothesis set at the beginning of this research. Thus, it can be noted that a medium-low level of PA, following the recommendations of international bodies like World Health Organization (WHO, 2010) or the U.S. Department of Health And Human Services (2008), is positively related to PMS and in a negative manner with NMS. Similarly, a low level of PA (where the minimum levels of practice recommended by these bodies are not reached) correlates in a negative manner with PMS and in a positive with NMS.

Nevertheless, data collected do not prove to be fundamental and it would be advisable to continue developing this line of work. It would also be interesting to analyze the consequences of diverse typologies of PA, and even of specific programmes of monitored PA during leisure time in different populations, in order to render values as objectively as possible for contrast purposes.

Similarly, it is necessary to consider some limitations of the research. On the one hand, the level of PA has been measured with IPAQ, an indirect method that can distort such values to a certain extent. It would be interesting for future research to carry out objective measures through the accelerometer or other objective tools. On the other hand, the type of PA practice has not been taking into account either, since only the levels have been considered. This factor may prove to be relevant because the psychological impact may be very different depending on whether the individual performs the PA during leisure time, within the field of recreation, or whether the PA is performed related to the occupation or framed within the work day.

\section{CONCLUSIONS}

In conclusion, it would be feasible to state that PA answering to the global recommendations of healthy practice would bring a beneficial effect on the MS of individuals, and therefore it would contribute to improving psychological health. Nevertheless, it is necessary to continue in this line of research to satisfactorily determine the effect that factors such as the levels of PA, the typology of PA or the characteristics of exercise (frequency, length and intensity), among others, have on MS and the psychological wellbeing of individuals.

\section{REFERENCES}

Andrade, E., Arce, C., Garrido, J., Torrado, J., \& De Francisco, C. (2011). Modelo de medida del estado de ánimo subjetivo en deportistas adolescentes. Revista de Psicologia Del Deporte, 20(2), 537-548.

Arruza, J. A., Arribas, S., Gil, D. L., Irazusta, S., Romero, S., \& Cecchini, J. A. (2008). The impact of duration in sport and physical activity on the psychological well-being. Revista Internacional de Medicina y Ciencias de la Actividad Fisica y del Deporte, 8, 171-183.

Arruza, J. A., Gil de Montes, L., \& Arribas, S. (2007). Actividad física y salud en la población adulta de Guipúzcoa. Retrieved from http://www.kirolbegi.net/docs/slides/PAFYD - Actividad Fisica y salud 2007.pdf.

Badenes, L. V., Prado-Gascó, V., \& Barrón, R. G. (2016). Conciencia emocional, estados de ánimo y personalidad, como predictors de las quejas somáticas en niños y adultos. Psicothema, 28(4), 383388. https://doi.org/10.7334/psicothema2015.265 
Barak, Y. (2006). The immune system and happiness. Autoimmunity Reviews, 5(8), 523-527. https://doi.org/10.1016/j.autrev.2006.02.010

Barra Almagiá, E. (2003). Influencia del Estado Emocional en la Salud Física. Influence of Emotional State on Physical Health. Terapia Psicológica, 21(1), 55-60.

Beedie, C. J., Terry, P. C., \& Lane, A. M. (2008). Journal of Applied Sport Psychology The profile of mood states and athletic performance: Two meta-analyses, (September 2014), 37-41. https://doi.org/10.1080/10413200008404213

Berger, B. G., \& Motl, R. W. (2000). Exercise and mood: A selective review and synthesis of research employing the profile of mood states. Journal of Applied Sport Psychology, 12(1), 69-92. https://doi.org/10.1080/10413200008404214

Bonet, J., Parrado, E., \& Capdevila, L. (2017). Original Estado de Ánimo y la Hrv. Revista Internacional de Medicina Y Ciencias de La Actividad Física Y El Deporte, 17(65), 85-100. https://doi.org/DOI: http://dx.doi.org/10.15366/rimcafd2017.65.006

Castañeda, C., Zagalaz, M. L., Chacón, F., Cachón, J., \& Romero, S. (2012). Características de la práctica deportiva en función del género. Estudiantes de la Facultad de Ciencias de la Educación: Universidad de Sevilla. RETOS. Nuevas Tendencias En Educación Física, Deporte Y Recreación, 25,4 .

Cervelló, E., Peruyero, F., Montero, C., González-Cutre, D., Beltrán-Carrillo, V. J., \& Moreno-Murcia, J. A. (2014). Ejercicio, bienestar psicológico, calidad de sueño y motivación situacional en estudiantes de educación física. / Exercise, psychological well-being, sleep quality and situational motivation in physical education students. Cuadernos de Psicología Del Deporte, 14(3), 31-38. https://doi.org/10.4321/S1578-84232014000300004

Chacón-Borrego, F., Corral-Pernía, J. A., \& Castañeda-Vázquez, C. (2017). Relación entre actividad física, estados de ánimo y género en personas adultas. European Journal of Health Research J. Health. Research, 3, 2445-308. Retrieved from www.ejhr.es

Cohen, S., Alper, C. M., Doyle, W. J., Treanor, J. J., \& Turner, R. B. (2006). Positive emotional style predicts resistance to illness after experimental exposure to rhinovirus or influenza $A$ virus. Psychosomatic Medicine, 68(6), 809-815. https://doi.org/10.1097/01.psy.0000245867.92364.3c

Craig, C. L., Marshall, A. L., Sjöström, M., Bauman, A. E., Booth, M. L., Ainsworth, B. E., ... Oja, P. (2003). International physical activity questionnaire: 12-Country reliability and validity. Medicine and Science in Sports and Exercise, 35(8), 1381-1395. https://doi.org/10.1249/01.MSS.0000078924.61453.FB

Deepthi, R., Ashakiran, S., Akhilesh, T. V., \& Reddy, M. (2015). Good mental status of medical students: Is there a role for physical activity? Journal of Krishna Institute of Medical Sciences University, 4(1), 55-63.

Department of Health And Human Services. (2008). Physical Activity Guidelines. Retrieved February 23, 2018, from https://health.gov/paguidelines/guidelines/chapter4.aspx

Fang, C. Y., Miller, S. M., Bovbjerg, D. H., Bergman, C., Edelson, M. I., Rosenblum, N. G., ... Douglas, S. D. (2008). Perceived stress is associated with impaired t-cell response to HPV16 in women with cervical dysplasia. Annals of Behavioral Medicine, 35(1), 87-96. https://doi.org/10.1007/s12160-007$\underline{9007-6}$

Fernández, R., Zurita, F., Cepero, M., Molina, V. A., Vilches, J. M., \& Ambris, J. (2015). Influence of the physical and psychological variables on physical injuries in football. Journal of Human Sport and Exercise, 10(3), 785-794. https://doi.org/10.14198/jhse.2015.103.04

García, C. R., Martínez-Rodríguez, A., \& Ortín, F. J. (2015). Dependencia al ejercicio físico e indicadores del estado de ánimo en deportistas universitarios. Cuadernos de Psicología Del Deporte, 15(2), $21-$ 26. https://doi.org/10.4321/S1578-84232015000200003 
García Ferrando, M., \& Llopis Goig, R., (2011). Ideal democrático y bienestar personal : encuesta sobre los hábitos deportivos en España 2010. [Madrid]: Consejo Superior de Deportes, Centro de Investigaciones Sociológicas.

Glaser, R., \& Kiecolt-Glaser, J. K. (2005). Science and society: Stress-induced immune dysfunction: implications for health. Nature Reviews Immunology, 5(3), 243-251. https://doi.org/10.1038/nri1571

Jiménez, M. G., Martínez, P., Miró, E., \& Sánchez, A. I. (2008). Bienestar psicológico y hábitos saludables: ¿Están asociados a la prática de ejercicio físico? International Journal of Clinical and Health Psychology, 8(1), 185-202.

Lawlor, D. a, \& Hopker, S. W. (2001). The effectiveness of exercise as an intervention in the management of depression: systematic review and meta-regression analysis of randomised controlled trials. BMJ (Clinical Research Ed.), 322(7289), 763-7. https://doi.org/10.1136/bmj.322.7289.763

Leon-Prados, J. A., Calvo-Lluch, A., \& Ramos-Casado, A. M. (2012). Physical activity and mood profile in a sector of seville's people | Actividad física y perfil anímico en un sector de la poblacion sevillana. Revista Internacional de Medicina Y Ciencias de La Actividad Fisica Y Del Deporte, 12(46), 271 286.

Ministerio de Sanidad Servicios Sociales e Igualdad. (2017). Informe Anual del Sistema Nacional de Salud $2016 . \quad$ Retrieved from https://www.msssi.gob.es/estadEstudios/estadisticas/sis/nfSanSNS/tablasEstadisticas/InfAnualSN S2016/Informe_Anual_SNS_2016_completo.pdf

Noce, F., De Oliveira Castro, H., Ferreira, T. S., Pereira De Andrade, A. G., \& Da Costa, V. T. (2016). A 6-month comparison of quality of life and mood states between physically active and sedentary college students. Medicina, 49(1), 9-16. https://doi.org/10.11606/issn.2176-7262.v49i1p9-16

Oiarbide, A., Martínez de Santos, R., Usabiaga, O., Etxebeste, J., \& Urdangarin, C. (2014). Efectos de los juegos de cooperación-oposición en el ánimo de los universitarios. Retos. Nuevas Tendencias en Educación Física, Deporte y Recreación, 25(10 trimestre), 58-62. Retrieved from http://www.retos.org/numero_25/58-62.pdf

Portela-Pino, I., Gutierrez-Sánchez, Á., Alonso-Fernández, D., \& De Vicuña, O. A. G. (2017). Comparative study on pre-competition mood in Canadian and Spanish university students. Journal of Human Sport and Exercise, 12(4), 1328-1336. https://doi.org/10.14198/jhse.2017.124.18

Pulver, A. E., Bartko, J. J., \& Carpenter, W. T. (1988). The power of analysis: statistical perspectives: part 1. Psychiatry Research, 23, 301-309. https://doi.org/10.1016/0165-1781(88)90020-0

Reed, J., \& Ones, D. S. (2006). The effect of acute aerobic exercise on positive activated affect: A metaanalysis. Psychology of Sport and Exercise, 7(5), 477-514. https://doi.org/10.1016/i.psychsport.2005.11.003

Rey, M., Blasco, T., \& Xavier, F. (2000). Efectos de un procedimiento de inducción de estados de ánimo sobre la autoeficacia. Anales de Psicologia, 16(1), 23-31.

Romero, S., Carrasco, L., Sañudo, B., \& Chacón, F. (2010). Physical activity and perceived health status in adults from seville. Revista Internacional de Medicina y Ciencias de la Actividad Fisica y del Deporte, 10, 380-392.

Ruiz, P. J., \& Baena, A. (2011). Efectos del ejercicio aeróbico sobre los estados de ánimo en mujeres mayores. Retos. Nuevas Tendencias En Educación Física, Deporte y Recreación, 20, 16-20. Retrieved from http://retos.org/pdf/retos20.pdf

Shin, Y., \& Colling, K. . (2000). Cultural verification and application of the Profile of Mood States (POMS) with Korean elders. Western Journal of Nursing Research, 22, 68-83. https://doi.org/10.1177/01939450022044278 
Taylor, S. E., Kemeny, M. E., Reed, G. M., Bower, J. E., \& Gruenewald, T. L. (2000). Psychological resources, positive illusions, and health. American Psychologist. US: American Psychological Association. https://doi.org/10.1037/0003-066X.55.1.99

Varo J., Martínez A., \& González M. (2003). Beneficios de la actividad física y riesgos del sedentarismo. Medicina Clínica, 121(17), 665-672. https://doi.org/10.1016/S0025-7753(03)74054-8

Vázquez, C., Hervás, G., Rahona, J. J., \& Gómez, D. (2009). Bienestar psicológico y salud: aportaciones desde la psicología positiva. Anuario de Psicología Clínica y de la Salud, 5(1), 15-28.

World Health Organization. (2010). Recomendaciones Mundiales sobre Actividad Física para la Salud. Geneva: WHO Library Cataloguing-in-Publication, (Completo), 1-58. https://doi.org/978 924359997 $\underline{7}$

Zurita, F., Espejo, T., Cofré, C., Martínez, A., Castro, M., \& Chacón, R. (2016). Influencia de la actividad física sobre la resilencia en adultos con dolor de hombro. SPORT TK-Revista EuroAmericana de Ciencias Del Deporte, 5(2), 53-58. Retrieved from http://revistas.um.es/sportk/article/view/264651/196321 